\title{
Negotiating 'Evil': Google, Project Maven and the Corporate Form
}

\author{
Penny Crofts and Honni van Rijswijk \\ University of Technology Sydney, Australia
}

\begin{abstract}
'Don't be evil' was part of Google's corporate code of conduct since 2000; however, it was quietly removed in April or May 2018 and subsequently replaced with 'do the right thing'. Questions were raised both internally and externally to the organisation regarding the substantive meaning of this imperative. Some have highlighted the company's original intentions in creating the code of conduct, while others have used the motto as a basis for critiquing the company-such as for its advertising practices, failure to pay corporate tax or the manipulation of Google-owned content. The imperative's removal occurred at a time when thousands of Google employees, including senior engineers, signed a letter protesting the company's involvement in Project Maven, a Pentagon program that uses artificial intelligence to interpret video imagery, which could in turn be used to improve the targeting capability of drone strikes. Employees asserted their refusal to be involved in the business of war and expressed their wariness of the United States government's use of technology. This article will examine the legal construct and concept of the corporation, and whether it is possible for corporations to not be evil in the twentyfirst century.
\end{abstract}

Keywords: Google; corporate law; evil; technology; corporate responsibility; Don’t be evil; tech companies.

\section{Introduction}

Now part of the Alphabet Inc. corporation, Google was incorporated on 4 September 1998 as a privately held company operating in a California garage. Two Stanford graduates had invented an ingenious method that ranked web pages according to how many other pages linked to them. Google's initial public offering was on 19 August 2004, at least three years after the motto 'don't be evil' was coined and adopted. Prospective shareholders were warned on the very day of Google's initial public offering that the company was willing to 'forgo some short-term gains' to do 'good things for the world' ${ }^{1}$ As of May 2017, the motto was visible in some ethically themed Google statements and materials, but it has since been superseded by Alphabetissued communications that replaced 'don't be evil' with 'employees of Alphabet and its subsidiaries and controlled affiliates should do the right thing - follow the law, act honourably, and treat each other with respect'. ${ }^{2}$ Although it is unclear precisely when the motto was replaced, the newest motto is narrower and less aspirational than the original. The original imperative of 'don't be evil' also prompted the ontological proposition that the actors within a corporation, as well as the corporation itself, had the propensity to be evil or otherwise. In contrast, the revised motto is directed instead at behaviour and avoids any implications regarding what the corporation can or should be. Additionally, although 'don't be evil' can be interpreted broadly to include legal, moral and ethical concerns, the new motto narrows the scope of ethical obligations; it only requires that subsidiaries and employees 'follow the law' and the narrower goals of the corporate form itself, aspirations that, as we argue below, provide no guarantee that behaviour is moral. The exact status of the two mottos is open to debate-they can be

\footnotetext{
${ }^{1}$ Morozov, "Don't Be Evil," 2

${ }^{2}$ Oravec, "Mottos and Ethical Statements," 222.
}

This work is licensed under a Creative Commons Attribution 4.0 International Licence. As an open access journal, articles are free to use with proper attribution. ISSN: 2652-4074 (Online) 
considered marketing slogans or aspirations and values. They have also formed the basis of Google's codes of conduct. In this article, we focus on the original motto because even though it has been replaced, it remains strongly associated with Googleand because challenges to Google have been, and continue to be, framed in terms of 'don't be evil'.

The motto 'don't be evil' was one of the most controversial, even mythical, aspects of Google. ${ }^{3}$ It has been variously applauded and disparaged as an albatross, ${ }^{4}$ as well as used as a standard with which to judge Google from both within the institution and externally to it. Employees used the motto 'don't be evil' as a basis from which to protest Google's involvement in the United States (US) Department of Defense artificial intelligence project that interpreted video imagery and that could be used to improve the targeting abilities of drone strikes (Project Maven). In response to employee's concerns, as on other occasions previously, Google executives retained the discourse of 'don't be evil' and engaged with ethical challenges in those terms. This article examines and challenges the motto of 'don't be evil' to ask a broader question: is it possible for corporations, particularly those involved in the rapidly evolving and relatively unregulated area of technology, to 'not be evil' in the twenty-first century? Answering this question requires revisiting the corporate form and the competing interests within the form.

Analysing the corporate form is particularly salient for technology firms. Despite examples such as Facebook, technology firms are currently regarded by the general public as being the most ethical of profitable corporations. ${ }^{5}$ This is mainly because technology firms tend to treat skilled employees very well - mainly so they can attract and retain the best engineers-and because they have increasingly embraced ethics as a marketing strategy. However, technology companies, including Google, have been plagued by scandals in recent years-including sexual harassment in the workplace, breaches of antitrust laws, censorship cases and technological innovations of weaponry. These scandals, along with the potential privacy concerns posed by the huge troves of personal data held by several technology companies, have seemingly not influenced the general public's perception of the bulk of technology companies' ethics. In contrast, Facebook has ranked poorly as an ethical company (despite excellent worker pay) due to the company's poor treatment of its customers-specifically, its failure to protect customers' privacy and its dishonest communication. ${ }^{6}$ Many technology companies make ethical claims that are similar to those of Google; for example, Microsoft asserts that it committed to empowering 'every person and every organization on the planet to achieve more'7 - this may not be as catchy as Google's 'don't be evil', but it has the virtue of being suitably ambitious and vague. The question of whether corporations can avoid evil is particularly relevant for technology companies due to a combination of factors. Many of these firms are oligopolies that individuals and governments alike depend on completely, though they have little to no capacity to independently remedy issues when they arise. Artificial intelligence and automated decision-making tools are increasing in power and centrality, and technology companies retain large troves of private data on which the state can rely or which it can sell. These companies are at the forefront of technological innovation and may be caught up with the factual question of what can be done rather than the normative question of whether it should be done. All these issues arise in a field in which there is little to no government regulation or intervention. ${ }^{8}$ Combined together, companies such as Google are so new and fluid, and the threats they pose to society are so invisible, that the legal system is struggling to impose sufficient values and restrictions. ${ }^{9}$ Accordingly, a coherent approach to addressing ethics, values and moral consequences is urgently needed.

Criminologists Steve Tombs and David Whyte argue that corporate structures necessarily generate asocial, irresponsible outcomes and that all corporations should be abolished. ${ }^{10}$ Given the unlikelihood of this occurring, one of the questions considered in this article is whether using a guiding motto such as Google's 'don't be evil' might be one way of negotiating the demands of the corporate form and approaching ethical questions that technological developments raise. We draw on Jurgen Habermas's theory regarding the gap between fact and norm to argue that Google should at least aspire to not be evil, rather than place shareholders' profits before ethics, and to only moderate behaviour in response to law. Habermas based his theory on the gap between the law's aspirations to be just and the realities of the legal system. ${ }^{11}$ Habermas contended that even

\footnotetext{
${ }^{3}$ Morozov, "Don't Be Evil."

${ }^{4}$ Hoofnagle, "Beyond Google and Evil."

${ }^{5}$ For more information, see Alcorn, "Americans think Microsoft the most ethical company".

${ }^{6}$ For example, see Doffman, "New Facebook Privacy Breach."

${ }^{7}$ See Microsoft "Compliance and Ethics."

8 Abbott, "Bridging the Gap."; Bennett Moses, "How to Think about Law."

${ }^{9}$ Morozov, "Don't Be Evil."

${ }^{10}$ Tombs, The Corporate Criminal.

${ }^{11}$ Habermas, Between Facts and Norms.
} 
though the legal system does not always achieve ideals such as justice empirically, the ideal is rightly accepted by citizens as engaged participants. This means that claims that are based on these ideals are valid, valuable and powerful, even though the legal system may not (ever) achieve these ideals. That is, even though the legal system may not achieve justice, it is still judged by the ideal of justice, and citizens continue to aspire to it. The power of the motto 'don't be evil' is frequently highlighted throughout this article, and we argue in favour of Google continuing to draw on the motto to constrain and challenge corporate decision-making.

This article begins by considering the legal principles of incorporation and by situating Google's motto within the historical and recent requirements that a business must generate public benefit. It highlights how Google was imbricated in a myriad of ethical challenges since its formation and how these challenges were framed and responded to within the terms of 'don't be evil', - thereby providing us with cases to test regarding whether this self-appointed framework provides something 'more'something more than lagging legal structures and background ethical frameworks; a way forward as we try to navigate a more just technology. The article then analyses Project Maven through the prism of the motto, Google's use of strategies of interpretation emphasising the contingency of evil, and the possible need for compromising the motto in favour of the pursuit of profit. It also considers the idea that corporations, specifically technology corporations, are incapable of not being evil. The article concludes on an optimistic note preferring Google to embrace ideals rather than profit, but points to the urgent need for legal intervention so that we can aspire to a more complex justice than that provided by algorithms.

\section{The Advantages of Incorporation and the Public Benefit}

Google's motto is an expression of the desire to do good while also being a successful corporation. It is not alone in the struggle to balance the desire to not be evil with the desire to profit. This tension is inherent in the corporation's historical development: 'A corporation ... may be defined in the light of history as a body created by law for the purpose of attaining public ends through an appeal to private interests' ${ }^{12}$ Incorporation is the creation of a legal subject that can be recognised as having a single identity or 'personhood' that is distinct from the human persons who comprise the corporation. Historically, from the first application of the corporate form to business enterprise, the reigning norm was that business associates receive the privilege of incorporation only on the condition that their enterprise would generate public benefits. ${ }^{13}$ In the United Kingdom (UK), early corporations were incorporated by special charter, following petitions made to Parliament. Charters were granted so that corporations like the East India Company could support the state's ambitions for an empire. ${ }^{14}$ Incorporation was recognised as a substantial privilege that the state bestowed on a group, which offered businesses the significant advantages of operating as a single entity that had jurisdictional authority, centralised management, perpetual succession, asset lock-in, entity shielding and (almost always in the present day) limited liability. ${ }^{15}$ The privilege of limited liability for owners and shareholdersprotection from risk - denotes that investors can only lose the capital that they choose to invest. So, if the company incurs losses that are higher than the value of the sum invested, then the owners or shareholders bear no further responsibility for this loss. This in turn means that 'investors will neither be made to pay the full financial losses of the corporation, nor be made to pay for the damage caused by the corporation when social harms are caused' ${ }^{16}$ Accordingly, investors can be strategic in avoiding payment of total losses. Additionally, the corporate privilege of entity shielding (i.e., the inverse of limited liability) protects the corporation from the debts of its stockholders. The firm's assets are locked in and can be safely specialised to the production process, which increases the firm's productivity. ${ }^{17}$ The advantages of incorporation are not available to natural persons who operate according to the general rules of property and contract.

Historically, incorporation was justified on the basis of public benefit. To justify receipt of these advantages from the public, the norm long governing the chartering of corporations, including business corporations, was that the associates had to be committed to a purpose that yielded exceptional public benefits. ${ }^{18}$ Although theorists such as Ciepley recall the historical requirement of public benefit, they also recognise that, from the nineteenth century onwards, the idea that incorporation was

\footnotetext{
12 Adams, "Economics and Jurisprudence."

${ }^{13}$ Ciepley, "Can Corporations Be Held to the Public Interest?"

${ }^{14}$ The East India Company conquered, subjugated and plundered vast tracts of South Asia. Therefore, although the company was originally incorporated for 'public benefit', the project of colonisation has since been challenged; Robins, The Corporation that Changed the World.

${ }^{15}$ Ciepley, "Can Corporations Be Held to the Public Interest?" 1004.

16 Tombs, The Corporate Criminal, 84.

${ }^{17}$ Ciepley, "Can Corporations Be Held to the Public Interest?" 133.

${ }^{18}$ Harris, "Industrializing English Law."
} 
justified on the basis of public benefit has been whittled away. This led to realist economist Milton Friedman asserting that 'there is one and only one social responsibility of business - to use its resources and engage in activities designed to increase its profits'. ${ }^{19}$ Friedman clearly articulated the existing paradigm and agenda for corporations - the maximisation of profit as both the functional and legal purpose of a corporation. ${ }^{20}$ This shift has become axiomatic in the public consciousness, and legal doctrine reveals an explicit recognition of shareholder primacy and profit maximisation:

A business corporation is organised and carried on primarily for the profit of the stakeholders. The powers of the directors are to be employed for that end. The discretion of directors is to be exercised in the choice of means to attain that end, and does not extend to a change in the end itself, to the reduction of profits, or to the nondistribution of profits among stockholders in order to devote them to other purposes. ${ }^{21}$

In Australia, the Corporations Act 2001 requires that directors are bound to act in good faith for the best interests of the corporation. $^{22}$ In the final report of the Royal Commission into Misconduct in the Banking, Superannuation and Financial Services Industry, Commissioner Hayne observed that the duty of directors to act in good faith in the best interests of the corporation and for a proper purpose demands consideration of more than the financial returns that will be available to shareholders in any particular period. ${ }^{23}$ However, unlike in the UK, the requirement that directors consider the interests of stakeholders beyond shareholders is not explicitly required under Australian legislation. ${ }^{24}$ Similarly, the principles of exclusive shareholder primacy and sole profit maximisation are limited in the US - that is, corporate decision-makers have much greater latitude today than the quotation from Dodge $v$ Ford above would suggest. ${ }^{25}$ Under the business judgement rule, there is a presumption that when the directors of a corporation make a business decision, they act on an informed basis, in good faith and in the honest belief that the action was taken in the best interests of the company. ${ }^{26}$ The business judgement rule is a relatively easy standard for a director to meet for ordinary decisions. ${ }^{27}$

Despite these minor restrictions on the pursuit of (short-term) financial returns, corporations are frequently criticised for putting profit before people - for being entities with 'legal personality, but presumably no interest in humanity' ${ }^{28}$ Wealth maximisation is the default norm in public-traded companies. ${ }^{29}$ However, Google conspicuously informed investors up front that it would sometimes pursue its social mission, even where doing so might not maximise shareholder wealth. In doing this, it is arguable that 'where investors are advised ex ante that a specific firm or class of firms might sometimes advance social benefits at the shareholders' expense, they cannot justly complain about unfair treatment' ${ }^{30}$ Google can legally opt out of the priority for making profit by memorialising its social commitments through statements in its charters or by-laws. Friedman explained this more nuanced point by using agency theory-specifically expressing that executives are agents of shareholders who have the responsibility to 'conduct the business in accordance with their [shareholders'] desires' ${ }^{31}$ According to Friedman, corporations can benefit non-shareholder stakeholders if this is what the shareholders desire. ${ }^{32}$ However, as demonstrated in a recent annual meeting for Alphabet Inc., independent shareholder proposals that criticised Google for concentrating power in the hands of a few executives and demanding structural change that would make the company more accountable to shareholders and broader stakeholders (including Chinese dissidents) were unsuccessful. ${ }^{33}$ This reflects a lack of agreement amongst shareholders regarding what values Google should pursue and whether non-shareholders should also benefit from them.

Google's motto, 'don't be evil', reflects a response to the social pressure on large technology organisations to define and disseminate their ethical stances as the influences of technology expand. ${ }^{34}$ Additionally, there are parallel developments of new

\footnotetext{
${ }^{19}$ Friedman, "The Social Responsibility of Business."

${ }^{20}$ Hiller, "The Benefit Corporation."

${ }^{21}$ Dodge v Ford Motor Company, 170 NW 668 (MI 1919).

${ }^{22}$ Corporations Act 2001 (Cth) s 181(1).

${ }^{23}$ For more information, see the Royal Commission into Misconduct in Banking, "Final Report."

${ }^{24}$ Companies Act $2006 \mathrm{~s} 172$.

${ }^{25}$ Munch, "Improving the Benefit Corporation."

${ }^{26}$ Schoenjahn, "New Faces of Corporate Responsibility."

${ }^{27}$ Hiller, "The Benefit Corporation."

${ }^{28}$ Munch, "Improving the Benefit Corporation," 170.

${ }^{29}$ Page, "Social Enterprise."

${ }^{30}$ Page, "Social Enterprise," 1381.

${ }^{31}$ Friedman, "The Social Responsibility of Business."

${ }^{32}$ Friedman, "The Social Responsibility of Business," 51.

${ }^{33}$ See Tiku, "Alphabet Shareholders."

${ }^{34}$ Oravec, "Mottos and Ethical Statements."
} 
business entities, such as the Benefit Corporation in the US; these entities are obligated to pursue public benefit along with the responsibility of returning profits to shareholders-in terms of profit and socially obligated corporate forms of business. ${ }^{35} \mathrm{In}$ the UK, Community Interest Companies (CICs) were introduced in 2005 and designed expressly to meet the needs of social enterprise. CICs are companies that are intended to produce a community benefit by dedicating their assets and much of their profits to that purpose. ${ }^{36}$ These new corporate forms can be considered attempts to disrupt the norm of 'business is business' ${ }^{37}$ Google is not alone in its quest to be an ethical business or to represent itself as one. However, the history of progressively managed corporations that retain their progressivism across generations is abysmal, ${ }^{38}$ which means a live question is whether 'virtuous corporate practices [are] compatible with shareholder capitalism?'39

\section{Google's Ethical Challenges}

In light of the default paradigm of profit in corporations, it may seem unfair to hold Google to the standard of 'don't be evil'; however, the motto arguably forms an ideal or bulwark that can be used against the default paradigm. It is also a standard by which the corporation holds itself..$^{40}$ Google is not only criticised in terms of its motto, but it responds to criticisms in those terms as well. ${ }^{41}$ The company and motto were created during a time of early internet culture, which emphasised openness, collaboration and mutual aid. Since then, internet culture has become monetarised..$^{42}$ In a digitally saturated landscape, internet organisations such as Google face ethical issues that are expanding in complexity and social importance, as well as legal and political scrutiny. Google is extremely profitable and ubiquitous, to the extent that 'google' is not only the name of the company, but also a verb (meaning 'to search the internet') ${ }^{43}$ Google has drastically grown since its origins in a garage; it is now the window through which most internet users see the internet, ${ }^{44}$ even surpassing Coca-Cola as the world's most recognised trademark. $^{45}$

Project Maven was not an isolated ethical challenge for Google. For example, although consumers believe that Google's services are highly listed because of their objective quality, 'Google has significant incentives to game its rankings, and there is clear evidence it has done so' ${ }^{46}$ Google is able to manipulate the search engine because the algorithms that a search engine uses cannot be patented; companies like Google have used this as a method for keeping such processes hidden through trade secret law and thus completely shielded from any governmental view. ${ }^{47}$ There are no regulations that govern search algorithms, though various jurisdictions possess sponsorship disclosure rules. ${ }^{48}$ Google has also been criticised for a conflict of interest: most of Google's revenue is derived from the advertising in websites that are subject to its ranking. ${ }^{49}$ Given the absence of any comparatively influential alternatives, Google has been able to inflate its price for advertising - the highest bidder for a given AdWord will win the war of internet visibility. Google can also use its power to punish those subject to its ranking for choosing another provider, as well as coerce future use of the defendants' services. ${ }^{50}$

This manipulation is exacerbated by Google's aggressive approach to vertical integration: the acquisition of companies by other companies so that the acquirer may operate from two or more levels in the same chain of distribution. Since its inception, Google has acquired nearly 100 other companies. This means Google owns some of the media content that it offers to searchers, rather than just indexing and influencing it. Google elevates the placement of its own links in the natural results page, without

\footnotetext{
${ }^{35}$ Hiller, "The Benefit Corporation.”; Blodgett, "Social Enterprise."

${ }^{36}$ Page, "Social Enterprise."

${ }^{37}$ Hanson, "The Situation."

${ }^{38}$ O'Toole, The Enlightened Capitalists.

${ }^{39} \mathrm{O}$ 'Toole, The Enlightened Capitalists.

${ }^{40}$ See https://www.amnesty.org/download/Documents/ASA1795522018ENGLISH.PDF

${ }^{41}$ The intra-discourse (self-articulation or self-definition of an institution) and inter-discourse (how institutions relate to each other) of Google have been framed in terms of the motto; Goodrich, Legal Discourse.

${ }^{42}$ Facebook's recent attempt to launch a crypto currency has met with significant opposition. See https://www.cnet.com/news/heres-whatyou-need-to-know-about-facebooks-controversial-libra-cryptocurrency/

${ }^{43}$ Auletta, Googled; additionally, Carroll also noted that 'google' became a verb in 2006; Carroll, "Don’t Be Evil."

${ }^{44}$ Carroll, "Don't Be Evil."

${ }^{45}$ Lastowka, "Google's Law."

${ }^{46}$ Carroll, "Don't Be Evil."

${ }^{47}$ Carroll, "Don't Be Evil."

48 The ACCC Digital Platforms Inquiry (2017-2019) suggested several potential ways that a forceful regulator could choose to make these entities more accountable.

${ }^{49}$ Carroll, "Don't Be Evil."

${ }^{50}$ Carroll, “Don’t Be Evil.”; see Kinderstart.com, LLC v Google, Inc 06-2057 WL 831806 (CA 2007).
} 
subjecting it to the search algorithm, which means that it can foreclose the competition. ${ }^{51}$ Therefore, the company's claim to be an algorithm-powered and neutral intermediary between the user and the collective mind of the internet is not true. These systems and biases have become so complex that no Google engineer fully understands them. ${ }^{52}$ Google meanwhile continues with its highly political work, even when it fails to notice the micropolitics involved.

Google has also been challenged for its operation in China. The ethical question that was asked was whether service to China should be abandoned or whether a new Google service engine (Google.cn) should be developed, with servers located in China that would submit to government censorship. Google chose the latter. ${ }^{53}$ In response to arguments declaring that this censorship breached human rights, Google's Vice President for Global Communications and Public Affairs, Elliot Shrage, maintained that the decision was compatible with Google's motto of 'don't be evil'. ${ }^{54}$ In a letter justifying Google's continued presence in China, Shrage asserted that:

We believe that knowledge is empowering and that a society with more information is better off than one with less. Providing
access to information to people around the world is central to our mission.

We believe continuing to explore opportunities in markets across the world, including in countries like China, is consistent with Google's mission to organize the world's information and with our commitment to create opportunity for everyone. ${ }^{55}$

This defence of censorship in terms of 'more information' is hypocritical, given Google's commodification of information in search engines through AdWorks. Despite the huge profits associated with the service, ethical reasoning ultimately led Google to withdraw its operation from China. However, it had since contemplated re-entry into the Chinese market with 'Dragonfly', which was subject to internal dissent by employees due to a lack of transparency and Google's capitulation on human rights.

Other ostensible violations of the motto have included issues of free speech, tax avoidance, violation of privacy through Google Street View, ${ }^{56}$ misappropriation, ${ }^{57}$ misinformation ${ }^{58}$ and the mistreatment of subcontracted service labourers who are invisible within Google's business model. ${ }^{59}$ A sense of disquiet has emerged regarding the use of search engines and social networks to collect data from private individuals ${ }^{60}$ — and sceptics assert that Google has been heavily complicit in turning the internet into a digital panopticon, one that has made privacy obsolete by treating information as a commodity and by turning access to knowledge into a profit-making venture. ${ }^{61}$ Since the mass killings in Christchurch, New Zealand, in March 2019, there have also been debates about the moral obligations of companies (including Google) and their role in the sharing of violent, extremist videos. $^{62}$

Despite these ethical challenges and failures, Google retains its reputation as one of the most reputable companies for corporate social responsibility; chief reputation officer of the Reputation Institute, Stephen Hahn-Griffiths, affirmed that 'Google is still viewed as an employer of choice. It's an aspirational, "do no evil" kind of company'. ${ }^{63}$ Despite ongoing ethical concerns about Google, Project Maven protests were framed unironically in terms of Google's motto, 'don't be evil'. In April 2018, thousands of Google employees, including senior engineers, signed a letter protesting Google's involvement in the Pentagon program. ${ }^{64}$ More than 3,100 employees signed the letter and outlined their concerns with Google creating warfare technology, with the first sentence stating: 'We believe that Google should not be in the business of war'. The letter explicitly protested in terms of the motto, asserting that 'Google's unique history, its motto Don't Be Evil, and its direct reach into the lives of billions of users set it apart'. ${ }^{65}$

\footnotetext{
${ }^{51}$ Carroll, "Don't Be Evil."

52 Morozov, "Don't Be Evil."

${ }^{53}$ Brenkert, "Google, Human Rights and Moral Compromise."

${ }^{54}$ Brenkert, "Google, Human Rights and Moral Compromise," 454.

${ }^{55}$ Letter from Walker to Amnesty International.

${ }^{56}$ Oravec, "Mottos and Ethical Statements."

${ }^{57}$ Huffman, "Developments in Social Media."

${ }^{58}$ Resende, "(Mis)Information Dissemination in WhatsApp."; Vaidhyanathan, Antisocial Media; Tani, "Fake News."

${ }^{59}$ Veith, “'Don’t Be Evil."”

${ }^{60}$ Oravec, "Mottos and Ethical Statements."

${ }^{61}$ Morozov, "Don't Be Evil."

${ }^{62}$ See https://www.abc.net.au/news/2019-03-19/new-zealand-facebook-christchurch-shooting-video-sheryl-sandberg/10915184

${ }^{63}$ Valet, "The World's Most Reputable Companies."

${ }^{64}$ Shane, "“The Business of War."”

${ }^{65}$ Google letter. https://static01.nyt.com/files/2018/technology/googleletter.pdf
} 


\title{
Balancing the Motto of 'Don't Be Evil' and Project Maven
}

This article will now analyse Google's response to Project Maven as a means of interrogating and complicating the motto 'don't be evil', and thinking through the legal and normative conception of the corporation, as well as the unique challenges of technological development.

\section{Project Maven and the Contingency of Evil}

One argument in relation to the motto involves emphasising the contingency of the definition of evil. Although both critics and supporters of Google confidently use the motto, the term 'evil' is contingent and constructed. There is a rich philosophy of wickedness that highlights shifts in the preferred definitions of evil throughout history. These include Aristotle's account of wickedness as a lack of balance, which was further developed by Aquinas as a lack grace, to meet thirteenth-century religious requirements. ${ }^{66}$ From the eighteenth century onwards, an emphasis was placed on 'evil as intentional wrongdoing that was reflected and reinforced in criminal law. ${ }^{67}$ This was then challenged after World War II by musings on the banality of evil and systemic failings. ${ }^{68}$ Post September 11, 2003, philosophies of evil were revived with George Bush's 'Axis of Evil'. ${ }^{69}$ Accordingly, different accounts of evil may emphasise intentional wrongdoing, harms done and/or evil as an effect of lack or failure.

The contingency of the concept of evil is highlighted by the various definitions of the term as posited by Google executives during the company's use of it. For example, Morozov has argued that the motto originally meant a refusal to mix advertisements with search results. Instead, links were clearly marked in a dedicated section on the site. The founders' letter that accompanied Google's initial public offering included the statement: 'We will live up to our "don't be evil" principle by keeping user trust and not accepting payment for search results'. Despite this narrow definition of 'evil', Google clearly no longer follows the principle of refusing to accept money for searches..$^{70}$ The responses of Google executives across time to the substance of the motto have not yielded much depth. For example, Marissa Mayer—one of Google's most senior executivesstated that the motto 'is good P.R. but really it's empty'. ${ }^{71}$ In 2005, former Executive Chairman of Google, Eric Schmidt, stated that 'evil is whatever Sergey [Brin] says is evil'. ${ }^{72}$ This reflects not only the capacity of those in power to shape definitions of evil, but also a certain frivolity and expediency in relation to the meaning of a motto that has become central to Google's selfimage. In 2013, Google proffered yet another interpretation of the motto:

\begin{abstract}
'Don't be evil.' Googlers generally apply those words to how we serve our users. But 'Don't be evil' is much more than that. Yes, it's about providing our users unbiased access to information, focusing on their needs and giving them the best products and services that we can. But it's also about doing the right thing more generally-following the law, acting honorably and treating each other with respect. ${ }^{73}$
\end{abstract}

Given the commodification of information, Google has failed the standard of providing 'unbiased access to information'. The aspiration of 'don't be evil' is what Google employees were debating when they protested the company's association with Project Maven. Project Maven is clearly lawful, but simple obedience to the law does not mean that one is behaving rightly. ${ }^{74}$ In response to the employee protests, Google issued a statement:

Any military use of machine learning naturally raises valid concerns ... We're actively engaged across the company in a comprehensive discussion of this important topic. ${ }^{75}$

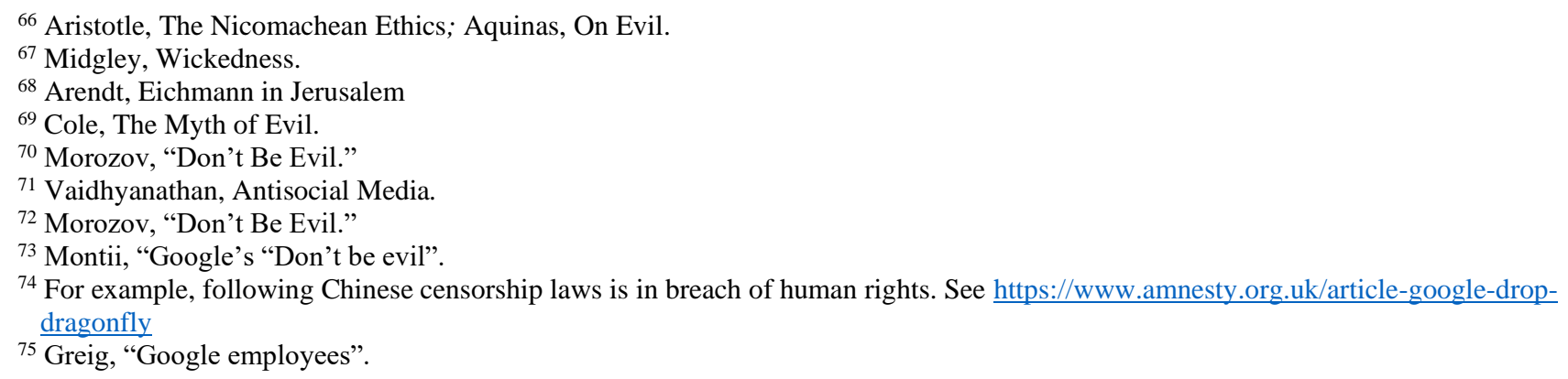


This statement reflects the notion of the contingency of evil. It also expresses a concern more generally about the unexpected impacts of artificial intelligence. Scientific developments have the potential to be used in ways that were unintended or unforeseen by creators - though the development of artificial intelligence for the military is clearly intended to be used in warfare.

Google defined part of its motto 'don't be evil' to be its commitment to an open workplace of creativity and accountability, which requires a 'culture of tolerance and respect, not a company full of yes men'. ${ }^{76}$ It was hoped that this would promote an atmosphere of creativity and challenge. There are internal message boards and social networks on which employees can challenge management and one another about Google's products and policies. It was this openness that enabled employees to challenge Google about Project Maven. However, despite claims of an open culture and Google responding to the criticism of Project Maven stating that such exchanges are 'hugely important and beneficial', several Google employees would only talk to journalists on condition of anonymity, stating that they were concerned about retaliation. ${ }^{77}$ In addition, even though 3,100 employees signed the letter protesting Project Maven, this was only a small proportion of Google's 70,000 plus employees, which underlines the differences of opinion about the definition of evil and expectations of Google. However, many of the signatories were senior engineers in the area of artificial intelligence research and thus extremely valuable and therefore privileged and powerful in their critique. Google is in intense competition with other technology companies for the most talented people. In the letter protesting Project Maven, these engineers argued that involvement with the Department of Defense would dissuade the best candidates from joining: 'This plan will irreparably damage Google's brand and its ability to compete for talent'. ${ }^{78}$ This argument was accordingly framed in terms that were idealistic but also commercial - appealing to Google's heart and mind within a framework of neoliberal competition. This highlights the perceptions of some employees who believe that the 'don't be evil' slogan is a powerful motivator. However, if Google fails to profit, it cannot offer the best salaries to the most talented and thus may lose some of the best engineers - reflecting once again, the difficulty of balancing profit with the desire to not be evil.

Google executives used the contingency of the definition of evil, highlighted by its expedient transformations across time, place and project in Google, in response to criticisms of Project Maven. Although the company's response sustained the motto of 'don't be evil', Google executives offered various forms of interpretive denial - that is, they admitted to building the software, but asserted that it was not evil. ${ }^{79}$ This is a method of sustaining the motto while still being engaging in Project Maven.

One form of interpretive denial was offered by Diane Greene, the leader of Google's cloud infrastructure business. She reassured concerned employees that Project Maven was 'specifically scoped to be for non-offensive purposes' ${ }^{80}$ Both Google and the Pentagon stated that the company's products would not, in themselves, create autonomous weapons systems that could fire without a human operator (a much-debated possibility in the area of artificial intelligence). The employees' letter did not accept this interpretation:

Recently, Googlers voiced concerns about Maven internally. Diane Greene responded, assuring them that the technology will not 'operate or fly drones' and 'will not be used to launch weapons.' While this eliminates a narrow set of direct applications, the technology is being built for the military, and once it's delivered it could easily be used to assist in these tasks. ${ }^{81}$

Building this technology to assist the US Government in military surveillance - and potentially lethal outcomes-is not acceptable. ${ }^{82}$

Accordingly, those who were critical of Project Maven did not accept Greene's 'non-lethal' argument. These concerns are legitimate. The Department of Defense has asserted that the infrastructure cloud procurement program was designed, in part,

\footnotetext{
${ }^{76}$ Google's Executive Chairman, Eric Schmidt, and Chief Economist, Hal Varian, stated this in Newsweek in 2005. See Oravec, "Mottos and Ethical Statements," 223.

77 Shane, "The Business of War."”

${ }^{78}$ See Shane, "The Business of War."”

${ }^{79}$ Cohen, States of Denial.

${ }^{80}$ Shane and Wakabayashi, "Thousands of Google workers."

${ }^{81}$ See Google letter: https://static01.nyt.com/files/2018/technology/googleletter.pdf

${ }^{82}$ See Google letter: https://static01.nyt.com/files/2018/technology/googleletter.pdf
} 
to 'increase lethality and readiness' ${ }^{83}$ This underscores the difficulties of 'separating software, cloud and related services from the actual business of war'. ${ }^{84}$

An additional argument from Google executives was that the technology was not evil because it was intended to save lives:

The technology is used to flag images for human review and is intended to save lives and save people from having to do highly tedious work. ${ }^{85}$

This is a consequentialist defence - if the improved analysis of drone video could better identify civilians and thus reduce the accidental killing of innocent people, then this can be considered a good outcome. However, the improved analysis could also be used to identify human targets for strikes. It should be noted that the Pentagon already routinely uses analysis of video available on Google in counter-insurgency and counter-terrorism operations - this artificial intelligence is just improving the accuracy of that analysis. ${ }^{86}$

An additional interpretive argument raised questions about the patriotism of Google employees for their refusal to assist the military. Former executive chairman, Eric Schmidt, stated that there was 'a general concern in the tech community of somehow the military-industrial complex using their stuff to kill people incorrectly, if you will'. ${ }^{87}$ This expresses an underlying notion that assisting the Department of Defense to 'correctly' kill people is not evil. Google already has links to the military, as Schmidt sits on the Pentagon's advisory board, the Defense Innovation Board, and has defended this position, stating that his presence on the Board was to 'at least allow for communications to occur' and that the military would 'use this technology help keep the country safe ${ }^{88}$ There is a perception that companies at the technological forefront will inevitably be drawn into world conflicts. Alvin and Heidi Toffler have pointed out that 'we make war the way we make wealth—with information' ${ }^{89}$ For example, by hosting combat footage on its subsidiary, YouTube, Google could already be described as being at war. It is argued that new technologies have always been adapted so they can be used on the battlefield - and artificial intelligence is a potentially transformational weapon. 'Silicon Valley's only real choice is which side it wants to win'. ${ }^{90}$ While employees in democratic countries may be able to refuse developing artificial intelligence for military purposes, employees in other countries may be compelled to advance military objectives and potentially leave democratic countries behind. ${ }^{91}$ This argument suggests that the refusal by Google's employees to help the US military is unpatriotic and potentially evil.

\section{'Don't Be Evil' versus the Profit Imperative: The Explicit Compromise of Values}

The above arguments of interpretation of the definition of evil reflect Google's desire to retain, or to at least be seen to retain, the motto while still undertaking controversial projects. An alternative approach is to explicitly compromise those valueswhich is when the questions of moral compromise and integrity arise. At certain times, these conflicting values cannot be rendered compatible. Some ethicists recognise that there are times when moral principles or values clash, and that this may require moral compromise. ${ }^{92}$ The business ethicist, George Brenkert, considered Google's engagement with China's selfcensorship requirement in terms of moral compromise and integrity. Brenkert's position is that people must be practical and nuanced when considering ethical questions in the context of corporate behaviour. Brenkert considered the situation of realising that certain justifiable values may require violation of other justifiable values, whose realisation cannot be made practically compatible with the first set of values. ${ }^{93}$ Brenkert argues that if business ethics holds to the importance of human rights and orders Google to leave, then it 'risks being cast as impractical and unrealistic, though idealistic and pure' ${ }^{94}$

\footnotetext{
${ }^{83}$ Shane, "The Business of War."”

${ }^{84}$ Shane, "“The Business of War."”

85 Shane, "“The Business of War."”

${ }^{86}$ See Pellerin, "Project Maven".

${ }^{87}$ See Scharre, "Eric Schmidt".

${ }^{88}$ See Scharre, "Eric Schmidt".

${ }^{89}$ Alvin, "A new theory of warfare".

${ }^{90}$ Cavanaugh, "Don't Be Evil."

${ }^{91}$ For more information, see https://www.wired.co.uk/article/artificial-intelligence-weapons-warfare-project-maven-google-china

92 Benjamin, Splitting the Difference. Other ethicists do not allow for the possibility of values and principles clashing and thus do not regard moral compromise as ethically permissible.

${ }^{93}$ Brenkert, "Google, Human Rights and Moral Compromise."

${ }^{94}$ Brenkert. "Google, Human Rights and Moral Compromise," 472.
} 
Brenkert attempts to apply ethical principles to corporations while acknowledging that profit is one of their core values. The value of this account is that it requires corporations to make arguments that justify moral compromise. Additionally, the moral compromise in this model is made explicit. The corporation makes the moral compromise due to other responsibilitiesparticularly profit - but may or may not still be guilty of a moral violation or of having performed a wrongdoing that was against its own values. Brenkert frames his ethical analysis with the argument that businesses often have multiple responsibilities to multiple stakeholders. Most major search engines and social media platforms are owned and controlled by corporate interests that often construe themselves as being responsible to some extent to shareholders, employees and other stakeholders - and are obligated to follow state laws, but are not applauded for being ethical while doing so. ${ }^{95}$ Businesses also operate within a market system, so what a business can do is conditioned by what other businesses do. Its continued existence depends on how well it fares with regard to its competitors. These shifting rules can be observed in claims by Google's engineers that part of the attraction of working at Google is its refusal to do evil.

In his application of ideas about Google's violation of its motto through its self-censorship in China, Brenkert elevates profit to a core value of business. He articulates four conditions that should be taken into account when considering moral compromise. This article will apply each in turn to Project Maven to consider Google's conundrum of balancing its motto with the quest for profit. The article will use the findings of Brenkert because his theory considers ethics seriously and because he locates morality within the real world of corporate values. The first condition to consider is fairness:

Do the demands of morality place an unfair or unrealistic burden on a moral agent such that the violation or infringement of some moral principle or rule seems warranted even though the principle or rule is otherwise justified ${ }^{96}$

This point raises the question of how much morality can demand. Applied to human beings, this point argues that any view of morality that requires individuals to act in ways that would significantly harm or destroy them over a substantial period of time is an unsatisfactory view of morality. ${ }^{97}$ De George extended the point by arguing that morality only demands that a person blows the whistle if he or she has credible evidence of likely harm and if he or she has good reason to believe that by releasing the truth to the public, the threatened harm will be prevented; in the absence of any clear chance of success, whistle blowers are not obligated to blow the whistle. ${ }^{98}$ With this argument, there is no need to sacrifice oneself, as there is no likelihood of positive gain. In line with this would be the argument that if Google chooses not to work with the Department of Defense, then its competitors will. For example, Amazon and Microsoft proudly promote their links with military and defence agencies. The protest letter directly engages with this issue by arguing the exceptionalism of Google:

By entering into this contract, Google will join the ranks of companies ... The argument that other firms, like Microsoft and Amazon, are also participating doesn't make this any less risk for Google. Google's unique history and its motto Don't Be Evil, and its direct reach into the lives of billions of users sets it apart. ${ }^{99}$

Corporate theorists such as Kim argued that unlike human beings, corporations have no inherent right to exist. ${ }^{100}$ This raises the question that, when it becomes impossible for a particular corporation to exist without doing wrong - or when we become aware that the corporate form is not serving human interests - should the particular corporation, or the corporate form in general, continue to be supported by law and society?

Brenkert's second condition requires evaluating the severity of the violation involved: what kind of harm does the violation threaten? Harmful consequences are much harder to justify, but aspects that can be taken into account are whether one is the sole source of harm or merely contributing to the wrongs involved. Does it add additional harm or participate in harms being imposed without increasing their magnitude? Are innocent bystanders harmed by the violation? The protest letter is framed in terms of the harmful consequences of the artificial intelligence: 'Building this technology to assist the US Government in military surveillance - and potentially lethal outcomes - is not acceptable'. ${ }^{101}$ In contrast, the acts of interpretation by Google executives considered in the section above arguably provide support for moral compromise. It could be argued that innocent

\footnotetext{
95 Oravec, "Mottos and Ethical Statements."

96 Brenkert, "Google, Human Rights and Moral Compromise."

${ }^{97}$ Brenkert. "Google, Human Rights and Moral Compromise," 469.

${ }^{98}$ de George, Competing with Integrity.

${ }^{99}$ See https://static01.nyt.com/files/2018/technology/googleletter.pdf

${ }^{100}$ Kim, "Characteristics of Soulless Persons."

${ }^{101} \mathrm{See}$ https://static01.nyt.com/files/2018/technology/googleletter.pdf
} 
bystanders would be safer if artificial intelligence could be more accurate: only the enemies of the state would need to fear the drones.

Brenkert's third condition is the implication for one's own integrity. One could argue that moral integrity requires Google to remain absolutely true to its commitments and to not compromise at all. This is what the employees called for in the protest letter: 'Google's stated values make this clear. Every one of our users is trusting us. Never jeopardize that. Ever' ${ }^{102}$ The letter also calls on market values, asking Google executives to protect the brand, a core component of which is the motto 'don't be evil'. However, in his consideration of integrity, Halfon notes that it is possible for people of integrity to 'reassess their ideals or principles and re-evaluate their commitments. What must be avoided by persons of integrity is abandoning their commitments for arbitrary or capricious reasons.' ${ }^{103}$ This could justify Google reconsidering its values, in light of the radical changes in the company and in the world since Google created its motto. Alternatively, Benjamin has argued that people can maintain their integrity when they accept positions of compromise if they protect the important values to which they adhere: ${ }^{104}$ 'To choose to preserve as best as possible the overall pattern of one's life cannot be regarded as betraying one's integrity. Indeed, in such circumstances, a compromise may provide the best means to preserving it.' ${ }^{105}$ On this point, Brenkert has argued that Google could soften the motto so that it becomes more of an ideal, rather than a rule that can never be violated. ${ }^{106}$

Brenkert's final condition when violating a moral demand is the need to attempt to mitigate the impact or seriousness of the violation. Are there ways in which Google could mitigate and reduce the compromise of the motto by involvement in Project Maven? Attaching conditions to how the Department of Defense uses Google-generated artificial intelligence is arguably one method of mitigating harms done; however, given that the Department of Defense has stated its aim as increased lethality, these conditions are unlikely to be met. The protesters did not accept the idea that the Department of Defense will maintain restrictions on use: 'We cannot outsource the moral responsibility of our technologies to third parties' ${ }^{107}$ The protesters instead believed that the only appropriate response was to immediately cancel the project and 'draft, publicize, and enforce a clear policy stating that neither Google nor its contractors will ever build warfare technology'. ${ }^{108}$

\section{Google, Give Up: It is Impossible for Corporations to Not Be Evil}

Brenkert has attempted to consider corporations as moral entities, by elevating profit to one of many competing values that a corporation may have. In contrast, criminologists Tombs and Whyte have argued that the private, profit-making corporation is a habitual and routine offender. They would disagree with Brenkert's attempts to portray the corporation as a moral, responsible citizen: their key argument is that corporations are supported by law and society to make profit. ${ }^{109}$ Whilst profit is a value for the corporation it is not a moral principle. The corporations' structure encourages short-termism, with the primary focus on immediate profit. Moreover, as Coffee has argued, corporations are so structured that our standard tools for holding them even to bare legality (e.g., punishing the legal entity or punishing culpable individuals) suffer from inherent limitations and fail to adequately deter corporate misconduct. ${ }^{110}$

The corporate form signifies the separation of ownership from control and the separation of responsibilities from the consequences of corporate decisions. Shareholders are legally protected from most of the negative consequences of company actions. Company executives are usually concerned with profitability and are often distanced from-and legally protected from the consequences of - the conditions of production. Executives may conceive the consequences abstractly and may, in turn, pressure managers to produce as much and as cheaply as possible. These effects of the corporation create forms of 'structural irresponsibility,' in which it is often difficult to identify how decisions are made and how well or how poorly the different

\footnotetext{
102 See https://static01.nyt.com/files/2018/technology/googleletter.pdf The italicised sentences were included in the letter.

103 Halfon, Integrity: A Philosophical Inquiry.

104 Benjamin, Splitting the Difference.

105 Benjamin, Splitting the Difference, 37.

106 Brenkert, "Google, Human Rights and Moral Compromise," 471.

107 See https://static01.nyt.com/files/2018/technology/googleletter.pdf

108 See https://static01.nyt.com/files/2018/technology/googleletter.pdf

109 Tombs, The Corporate Criminal.

${ }^{110}$ Coffee Jr, "No Soul to Damn."
} 
components of production relate. ${ }^{111}$ Tombs and Whyte argued that corporate structures necessarily generate asocial and irresponsible outcomes: ${ }^{112}$

Paradoxically, then, the limited liability corporation—based on the notion of the corporate 'person'—has a dehumanising effect. In other words, the primary function of corporate personhood is actually to depersonalise the human consequences of the corporation: to remove its human content. The corporate form removes the necessity for the human consequences of its decisions to be considered at all by its owners. ${ }^{113}$

Interestingly, the protest letter is framed in personal terms, as the letter is addressed to the CEO ('Dear Sundar'), and Google's responses to Project Maven and the motto more generally have been in personal terms. This may underline Google's exceptionalism in its willingness to name people rather than to retain a depersonalised corporation. Alternatively, it may reflect the concerns of the recent shareholder meeting about the increasing centralisation of executives at Google. Despite this, Google has demonstrated a willingness to make expedient decisions when the values of profit and 'don't be evil' are in conflict.

However, are technology companies specifically capable of not being evil? There are current views-as well as cultural fears and myths - that there is something inherent to technology that renders it uniquely likely to exceed human control. For example, one of the founders of DeepMind, (which created Evil Genius), Shane Legg, has predicted that the threat of artificial intelligence running amok is the greatest existential threat to humans in this century. Legg asked Google to establish an 'ethics board' to consider the appropriate use of machine learning in its products and to ensure that Google follows its motto. ${ }^{114}$ In response, Google established the Advanced Technology External Advisory Council-but this was almost immediately dissolved due to controversy as to the selection of council members. ${ }^{115}$ But also at play are dystopian myths about technology (e.g., portrayed in science fiction such as The Terminator, or The Matrix), which reflect fears that technology dominates or will dominate all aspects of culture and society. ${ }^{116}$ A more nuanced argument can be made that technology companies understand the world and view it through the epistemologies of science and quantifiable data. In 1968, Jurgen Habermas presciently argued that 'technocratic consciousness' represses and then evicts ethics from the constitution and regulation of the public life. The technocratic consciousness reduces values to fact-based empirical questions that are resolved through data. Habermas argued that the permeation of technology and science in social institutions destroys the old legitimations and that it removes the social framework of interests — in which strategies are chosen, technologies are applied and system are established-from the scope of reflection and rational reconstruction. ${ }^{117}$ Technology becomes the measure of all things, and the only measure of value. The central values of technology are utility, optimisation and efficiency. These values are then linked to the neoliberal corporate quest for profit. ${ }^{118}$

Journalist and social commentator, Morozov, has drawn upon Habermas to argue that Google has consistently portrayed technocractic consciousness, highlighting the high-profile Google executive who proclaimed that 'technology is a part of every challenge in the world and a part of every solution'. He argues that Google is blinded to the non-technological side of human life. ${ }^{119}$ Although the company's methodology is appropriate in the realms of information theory and computer science, its technological developments have placed Google (and other technology companies) in the moral and social domains of issues such as privacy and information dissemination. As previously argued, there have been numerous ethical challenges since Google's incorporation; these first surprised Google, and then Google managed them poorly, if at all. Google has demonstrated its willingness to use its power and clout to expand the reach of technological innovation without considering any negative impacts. The question regarding the development of artificial intelligence is not the factual question of whether it can be done, but the normative question of whether it should be done.

Morozov argues that Google has been blind to the distinction between the factual and the normative: ${ }^{120}$

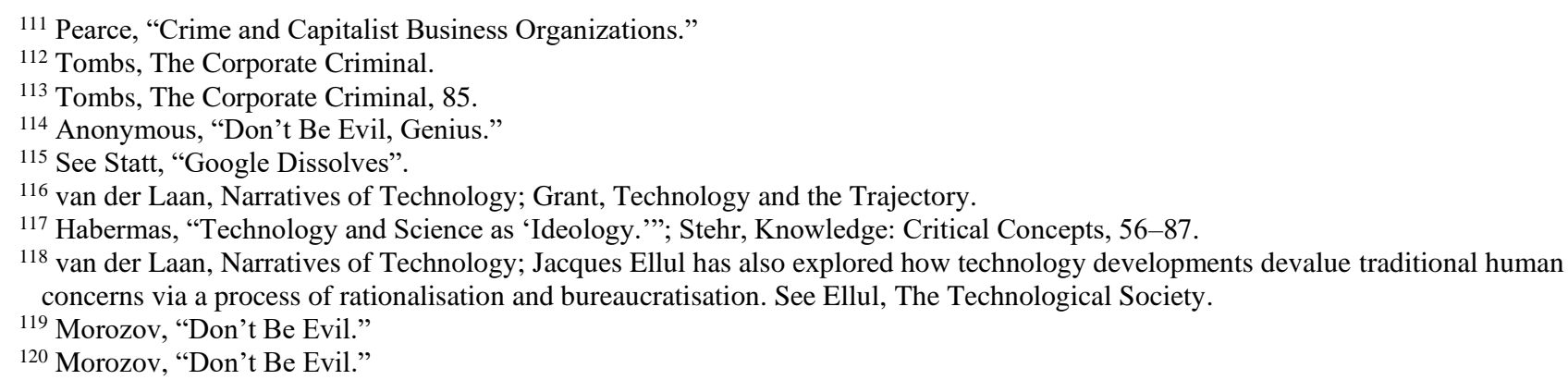


Time and again, its engineers fail to anticipate the loud public outcry over the privacy flaws in its products, not because they lack the technical knowledge to patch the related problems but because they have a hard time imagining an outside world where Google is seen as just another greedy corporation that might have incentives to behave unethically. ${ }^{121}$

This attempt to reduce the normative to the quantifiable returns us to the contingency of the definition of evil. On this account, even Google's 'don't be evil' motto does not protect against the evil of Google. 'Worst of all', argues Morozov, 'Google refuses to acknowledge this Kafkaesque dimension of its work, denying the victims of its "algorithmic justice" a way to rectify the situation or even to complain about it'. ${ }^{122}$ Google has not acknowledged the political effects of its operations, nor has it accepted that algorithms can be as flawed or as biased as the coders who write them. It has not accepted the need to help users report what it has done wrong without having to sue. This is an issue of information injustice which cannot be resolved with quantitative data:

We need to think more carefully about how to regulate to protect values and minimise harm in light of an evolving sociotechnical landscape rather than simply asking how technology ought to be regulated'. ${ }^{23}$

Demands that businesses should act ethically in international settings have markedly increased, including in the specific concerns of sweatshops, the environment, transfer pricing and human rights violations. ${ }^{124}$ In this sense, the market, rather than external legal regulation, could possibly govern corporations. However, market regulation has proven itself to be insufficient and dominated by a technocratic, neoliberal consciousness. This is not just an argument for the regulation of technology; it is also one for the regulation of the corporations that develop and use that technology. There is a large body of academic literature focusing on the legal system's failure to adequately regulate corporations. ${ }^{125}$ The research suggests that the larger the corporation, the larger the harms it is capable of inflicting and the less likely it is to be held accountable. ${ }^{126}$ There is also an increasing recognition that the system is failing to adequately regulate technological developments. ${ }^{127}$ As such, it is clear that companies such as Google are so new and fluid — and the threats that they pose to society are so invisible — that the legal system struggles to impose sufficient values and restrictions. ${ }^{128}$ Although it is a positive decision for Google to retain its aspiration of 'don't be evil', law should impose and protect values that we as a society hold dear upon corporations and technological development. Despite its motto, Google has not demonstrated a willingness to impose the limits and values upon itself.

\section{Conclusion: Some of Google's Ethical Challenges}

Although the motto 'don't be evil' can be disparaged as sloganistic and simplistic, ${ }^{129}$ it does possess a power that is granted by the framing of protest and the response within its terms. The motto reflects a central myth that Google is exceptional - that it is a noble academic exercise that just happens to earn money on the side. ${ }^{130}$ This forms part of the anti-corporate myth of Google's initial creation, initiated by two young guys starting an internet tool for the benefit of people. Despite this story of origins, Google has since become hardened into corporate form and, once incorporated, it has the legal requirement of benefiting shareholders. In turn, although the regulation of corporations may soften this requirement, the effect of this structure is to render the profit imperative paramount - and this imperative is ethics neutral. Additionally, companies such as Google reflect and reinforce a technocratic consciousness that elevates quantitative values such as utility and productivity over normative values such as justice and equality. Accordingly, if perfecting drones is the most profitable future direction, then that is where the public company should and will go. This is even more so in the case for a public company when compared to a private company and an unincorporated venture, because of the profit momentum created by the corporate structure.

Given Tombs and Whyte's arguments, it may be appropriate for Google to simply stop trying to not be 'evil'. Replacing the motto with 'do the right thing' is arguable an expression of this attempt. Rather than external arguments and evaluations of what it means to be evil, the motto 'do the right thing' arguably reduces the ethical standard to simply mean 'do the right thing

\footnotetext{
${ }^{121}$ Morozov, "Don’t Be Evil."

122 Morozov, "Don't Be Evil."

${ }^{123}$ Bennett Moses, "Agents of Change," 787.

${ }^{124}$ Brenkert, "Google, Human Rights and Moral Compromise."

${ }^{125}$ Braithwaite, "Taking Responsibility Seriously."; Wells, "Corporate Criminal Liability."

${ }^{126}$ Veitch, Law and Irresponsibility.

127 Abbott, "Bridging the Gap."; Bennett Moses, "How to Think about Law."

${ }^{128}$ Morozov, "Don't Be Evil.",

${ }^{129}$ Oravec, "Mottos and Ethical Statements."

${ }^{130}$ Morozov, "Don’t Be Evil."
} 
... for Google'. If, as Tombs and Whyte argue, the central purpose of a corporation is profit, then the best corporation yields the most profit (from a teleological perspective). ${ }^{131}$ With this argument, Google should stop its superficial ethical hand wringing — which has mainly yielded expedient decisions — and simply embrace the pursuit of profit.

However, it should be asked whether we would prefer a corporation that at least aspires to not be evil, rather than one that wholeheartedly pursues and privileges profit above all else (keeping in mind Drucker's argument that the corporation can only flourish in the long term if the society in which it is placed likewise flourishes). ${ }^{132}$ The argument regarding Google's aspiration to not be evil in contrast to its realistic ability to act in this way is analogous to that of the law's aspiration to be just in contrast to the realities of the legal system. Jurgen Habermas also highlighted this tension between facts and norms-between what the legal system actually achieves and its self-proclaimed ideals. ${ }^{133}$ There is often a stark divide between the realists who highlight the failings of the system and the idealists who construct abstract models of justice. Habermas contends that ideals such as justice are rightly accepted by citizens as engaged participants, even though the legal system does not always empirically achieve these ideals. This means that claims based on these ideals are valid, valuable and powerful, even though the legal system may not (ever) achieve these ideals. This tension between facts and norms is part of common parlance-we make and accept speech claims that promise more than can be possibly delivered in reality. And it is of value that we do so. Even though the legal system may not achieve justice, we still judge the system by the idea of justice and continue to aspire to it. This suggests that Google can and should retain the motto of 'don't be evil' - a motto to which the company should aspire and from which it can constrain and challenge its corporate decision-making.

\section{Acknowledgments}

Many thanks to Ellen O'Brien for her excellent research assistance throughout this project. Thank you to Jason Schultz for drawing our attention to the motto.

Penny Crofts' research on corporations is funded by an Australian Research Council Grant Rethinking Institutional Culpability: Criminal Law, Horror and Philosophy (DE18010057).

\section{Bibliography}

Abbott, Carolyn. "Bridging the Gap-Non-State Actors and the Challenges of Regulating New Technology." Journal of Law and Society 39, no 3 (2012): 329-358. https://doi.org/10.1111/j.1467-6478.2012.00588.x

Adams, Henry Carter. "Economics and Jurisprudence." Economics Studies 2, no 1 (1897): 7-35.

Alcorn, Chauncey. Alcorn, "Americans think Microsoft is the most ethical company. Facebook, not so much." CNN Business, November 12, 2019. https://edition.cnn.com/2019/11/12/business/just-100-list/index.html

Anonymous, "Don't be evil, genius". The Economist, February 1, 2014. https://www.economist.com/business/2014/02/01/dont-be-evil-genius

Aquinas, Thomas. On Evil. Translated by Richard Regan. New York: Oxford University Press, 1274.

Arendt, Hannah. Eichmann in Jerusalem: A Report on the Banality of Evil. London: Penguin, 1994.

Aristotle. The Nicomachean Ethics. Translated by James Thomson. London: Penguin, 2004.

Auletta, Ken. Googled: The End of the World as We Know It. New York: Penguin, 2009.

Australian Competition and Consumer Commission. Digital Platforms Inquiry: Final Report. Australia: Commonwealth of Australia, 2019. https://www.accc.gov.au/focus-areas/inquiries-ongoing/digital-platforms-inquiry

Benjamin, Martin. Splitting the Difference: Compromise and Integrity in Ethics and Politics. Lawrence: University of Kansas Press, 1990.

Bennett Moses, Lyria. "How to Think about Law, Regulation and Technology: Problems with 'Technology' as a Regulatory Target." Law, Innovation and Technology 5, no 1 (2013): 1-20.

Blodgett, Mark S., Linda J. Melconian and Jason H. Peterson. "Social Enterprise: Raffirming Public Purpose Governance Through Shared Value.” Journal of Business and Securities Law 16, no 2 (2016): 305-328.

\footnotetext{
${ }^{131}$ Aristotle, The Nicomachean Ethics. This argument can be applied to the television series, True Blood. If the vampires are created to drink blood, then they should embrace and enjoy the lifestyle like the character Eric Northman, rather than feel guilty about it like the character Bill.

${ }^{132}$ Drucker, Post-Capitalist Society.

${ }^{133}$ Habermas, Between Facts and Norms.
} 
Braithwaite, John. “Taking Responsibility Seriously: Corporate Compliance Systems.” In Corrigible Corporations and Unruly Law, edited by Brent Fisse and P. French, 49-63. San Antonio: Trinity University Press, 1985.

Brenkert, George G. "Google, Human Rights and Moral Compromise.” Journal of Business Ethics 85 (2009): 453-478. https://doi.org/10.1007/s10551-008-9783-3

Carroll, Andrew. "Don't Be Evil ... Unless It Increases Revenue: What the Operation of Credit Rating Agencies Can Teach Us about Google.” Temple Journal of Science, Technology \& Environmental Law 31, no 1 (2012): 93-118.

Cavanaugh, M. L. "Don’t Be Evil, Support the Troops.” Wall Street Journal, April 17, 2018.

Ciepley, David. "Can Corporations Be Held to the Public Interest, or Even to the Law?" Journal of Business Ethics 154, no 4 (2019): 1003-1018. https://doi.org/10.1007/s10551-018-3894-2

Coffee Jr, John. "No Soul to Damn: No Body to Kick: An Unscandalized Inquiry into the Problem of Corporate Punishment." Michigan Law Review 79, no 3 (1980): 386-489.

Cohen, Stanley. States of Denial: Knowing about Atrocities and Suffering. Cambridge: Polity, 2001.

Cole, Phillip. The Myth of Evil. Edinburgh: Edinburgh University Press Ltd, 2006.

de George, Richard T. Competing with Integrity in International Business. New Jersey: Prentice-Hall, n.d.

Doffman, Zak. "1.5m Users Hit by new Facebook Privacy Breach as Extent of Data Misuse Exposed." Forbes, April 18, 2019. https://www.forbes.com/sites/zakdoffman/2019/04/18/facebook-illegally-harvested-data-from-1-5m-users-as-itleveraged-its-data-machine/\#26b38a196a2e

Drucker, Peter. Post-Capitalist Society. New York: HarperBusiness, 1993.

Ellul, Jacques. The Technological Society. Toronto: Vintage, 1967.

Friedman, Milton. "The Social Responsibility of Business Is to Increase Its Profits." New York Times Magazine, September 13, 1970.

Goodrich, Peter. Legal Discourse. London: Palgrave, 1987.

Grant, David and Bennett Moses, Lyria. Technology and the Trajectory of Myth. Australia: Edward Elgar, 2017.

Greig, Jonathan. "Google employees demand end to company's AI work with Defense Department". TechRepublic, April 5, 2018. https://www.techrepublic.com/article/google-employees-demand-end-to-companys-ai-work-with-defensedepartment/

Habermas, Jurgen. Between Facts and Norms: Contribution to a Discourse Theory of Law and Democracy. Cambridge: Polity, 1996.

Habermas, Jurgen. Technology and Science as Ideology. London and New York: Routledge, 2004.

Halfon, Mark S. Integrity: A Philosophical Inquiry. Philadelphia: Temple University Press, 1989.

Hanson, Jon, and David Yosifon. "The Situation: An Introduction to the Situational Character, Critical Realism, Power Economics, and Deep Capture.” University of Pennsylvania Law Review 152, no 1 (2003): 129-346. https://doi.org/10.2307/3313062

Harris, Ron. "Industrializing English Law: Entrepreneurship and Business Organization, 1720-1844." Cambridge: Cambridge University Press, 2000. https://doi.org/10.1017/CBO9780511510137

Hiller, Janine S. "The Benefit Corporation and Corporate Social Responsibility." Journal of Business Ethics 118, no 2 (2013): 287-301. https://doi.org/10.1007/s10551-012-1580-3

Hoofnagle, Chris J. "Beyond Google and Evil: How Policy Makers, Journalists and Consumers Should Talk Differently about Google and Privacy." First Monday 14, no 4 (2009): 4-6.

Huffman, Brandon J. "Developments in Social Media: First Amendment, Privacy, and Misappropriation." The Business Lawyer 71, no 1 (2015-2016): 305-319.

Kim, Susanna M. "Characteristics of Soulless Persons: The Applicability of the Character Evidence Rule to Corporations." University of Illinois Law Review 2000, no 3 (2000): 763.

Lastowka, Greg. “Google's Law.” Brooklyn Law Review 73, no 4 (2008): 1327.

Microsoft. Compliance and Ethics at Microsoft. https://www.microsoft.com/en-us/legal/compliance/default.aspx

Midgley, Mary. Wickedness: A Philosophical Essay. London: Routledge, 2001.

Montti, Roger. “Google's 'Don't be evil' no longer prefaces code of conduct”. Search Engine Journal, 20 May 2018.

Morozov, Evgeny. “Don't Be Evil.” The New Republic, July 13, 2011. https://hci.stanford.edu/courses/cs047n/readings/morozov-google-evil.pdf

Munch, Steven. "Improving the Benefit Corporation: How Traditional Governance Mechanisms Can Enhance the Innovative New Business Form.” Northwestern Journal of Law and Policy 7, no 1 (2012): 170-195.

Oravec, Jo Ann. "Mottos and Ethical Statements of Internet-Based Organizations: Implications for Corporate Social Responsibility." International Journal of Civic Engagement and Social Change 1, no 2 (2014): 37-53.

O'Toole, James. The Enlightened Capitalists: Cautionary Tales of Business Pioneers Who Tried to Do Well by Doing Good. New York: HarperCollins Publishers, 2019.

Page, Antony, and Robert A. Katz. "Is Social Enterprise the New Corporate Social Responsibility?" Seattle University Law Review 34, no 4 (2011): 1351-1384. 
Pearce, Frank. "Crime and Capitalist Business Organizations." Shover, Neal, and Wright, John (Eds) Crimes of Privilege . New York: Oxford University Press, 2001: 35-48.

Pellerin, Cheryl. "Project Maven to Deploy Computer Algorithms to War Zone by Year's End." US Dept of Defense: DOD News. July 21, 2017. https://www.defense.gov/Explore/News/Article/Article/1254719/project-maven-to-deploycomputer-algorithms-to-war-zone-by-years-end /

Resende, Gustavo, Philipe Melo, Hugo Sousa, Johnnatan Messias, Marisa Vasconcelos, Jussara Almeida and Fabrício Benevenuto. "(Mis)Information Dissemination in WhatsApp: Gathering, Analyzing and Countermeasures.” In $W W W$ '19: The World Wide Web Conference, edited by Ling Liu and Ryen White, 818-828. Proceedings of the World Wide Web Conference 2019. New York: Association for Computing Machinery, 2019. https://doi.org/10.1145/3308558.3313688

Robins, Nick. The Corporation that Changed the World: How the East India Company Shaped the Modern Multinational. London: Pluto, 2012.

Royal Commission into Misconduct in the Banking, Superannuation and Financial Services Industry. Final Report. Australia: Commonwealth Government, 2019.

Schoenjahn, Ashley. "New Faces of Corporate Responsibility: Will New Entity Forms Allow Businesses to Do Good?" Journal of Corporation Law 37, no 2 (2012): 453.

Shane, Scott, and Wakabayashi, Daisuke. “"The Business of War': Google Employees Protest Work for the Pentagon.” The New York Times, April 4, 2018. https://www.nytimes.com/2018/04/04/technology/google-letter-ceo-pentagonproject.html

Shane, Scott, and Wakabayashi, Daisuke. "Thousands of Google workers sign letter urging CEO to pull out of Pentagon AI project." The New York Times, April 4 2018. https://www.cnbc.com/2018/04/04/google-workers-urge-ceo-sundar-pichaito-pull-out-of-pentagon-project.html

Sharre, Paul, Cho, Anthony, Allen, Gregory, and Schmidt, Eric. "Eric Schmidt Keynote Address at the Centre for a New American Security Artificial Intelligence and Global Security Summit.” CNAS, November 13, 2017. https://www.cnas.org/publications/transcript/eric-schmidt-keynote-address-at-the-center-for-a-new-american-securityartificial-intelligence-and-global-security-summit

Statt, Nick. "Google dissolves AI ethics board just one week after forming it." The Verge, April 4, 2019. https://www.theverge.com/2019/4/4/18296113/google-ai-ethics-board-ends-controversy-kay-coles-james-heritagefoundation

Stehr, Nico and Reiner Grundmann (eds). Knowledge: Critical Concepts. London: Routledge, 2005.

Tani, Maxwell. "Fake News about the Las Vegas Shooting Spread Wildly on Facebook, Google, and Twitter." Business Insider Australia, October 3, 2017. https://www.businessinsider.com.au/las-vegas-shooting-mandalay-bay-facebooktwitter-google-2017-10?r=US\&IR=T

Tiku, Nitasha. “Alphabet Shareholders Demand Accountability.” Wired, June 19, 2019. https://www.wired.com/story/googles-troubles-encroach-alphabets-shareholder-meeting/

Toffler, Alvin, and Toffler, Heidi. "A new theory of warfare: The third wave arrives: We make war the way we make wealth: With information". Los Angeles Times, March 5 1991. https://www.latimes.com/archives/la-xpm-1991-03-05-me-22story.html

Tombs, Steve, and David Whyte. The Corporate Criminal: Why Corporations Must Be Abolished. London: Taylor and Francis, 2015.

Vaidhyanathan, Siva. Antisocial Media: How Facebook Disconnects Us and Undermines Democracy. New York: Oxford University Press, 2018.

Valet, Vicky. “The World's Most Reputable Companies for Corporate Responsibility in 2018.” Forbes, October 11, 2018. https://www.forbes.com/sites/vickyvalet/2018/10/11/the-worlds-most-reputable-companies-for-corporate-responsibility2018/\#51824bde3371

van der Laan, James M. Narratives of Technology. New York: Palgrave MacMillan, 2016.

Veitch, Scott. Law and Irresponsibility: On the Legitimation of Human Suffering. Oxon: Routledge, 2007.

Veith, Alison Agnes. “'Don’t Be Evil': Google's Labor, Technology, and the Limits of Corporate Good.” Master's Thesis, San Francisco State University, 2015.

Walker, Kent. Senior Vice President for Global Affairs, Google LLC, to Amnesty International. October $26,2018$. https://www.amnesty.org/download/Documents/ASA1795522018ENGLISH.PDF

Wells, Celia. “Corporate Criminal Liability: A Ten Year Review.” Criminal Law Review, no 12 (2014): 849-878.

\author{
Primary Legal Material \\ Companies Act 2006 (UK). \\ Corporations Act 2001 (Cth). \\ Dodge v Ford Motor Company, 170 NW 668. \\ Kinderstart.com, LLC v Google, Inc 06-2057 WL 831806 (CA 2007).
}

